\title{
Oral Glucose Tolerance, Insulin and Gastric Inhibitory Polypeptide Secretion in Patients Recovered from Acute Myocardial Infarction
}

\author{
S. Larsen ${ }^{1}$, K. B. Lauritsen ${ }^{2}$ and I. Christiansen ${ }^{1}$ \\ ${ }^{1}$ Division of Cardiology, Department of Internal Medicine and ${ }^{2}$ Department of Surgical Gastroenterology, Hvidovre Hospital, \\ University Hospital of Copenhagen, Denmark
}

\begin{abstract}
Summary. Ten male patients, recovered from acute myocardial infarction, and ten control subjects were investigated by a $50 \mathrm{~g}$ oral glucose tolerance test. All patients and control subjects had normal glucose tolerance, but the patients had increased fasting and integrated insulin response to oral glucose. Fasting gastric inhibitory polypeptide concentrations and integrated gastric inhibitory polypeptide response were normal in the patients. The exaggerated insulin secretion in patients recovered from myocardial infarction does not seem to be caused by increased secretion of gastric inhibitory polypeptide.
\end{abstract}

Key words: Oral glucose tolerance, insulin, GIP, myocardial infarction, coronary artery disease.

Plasma glucose and plasma insulin after oral glucose are increased in patients with coronary heart disease $[1,2]$. In contrast IV glucose has a variable effect on insulin release in patients with coronary heart disease [3]. These observations suggest a possible hyperfunction of the entero-insular axis mediating the hyperinsulinism. Gastric inhibitory polypeptide (GIP) exerts a glucose dependent insulinotropic effect causing insulin release in the hyperglycaemic state [4]. We have studied the role of GIP in hyperinsulinaemia in patients after acute myocardial infarction.

\section{Material and Methods}

The group consisted of 10 males, fully mobilized on a normal diet. All had suffered an uncomplicated acute myocardial infarction 8-10 weeks before the investigation. They were $40-55$ years of age and with a weight distribution of $95-125 \%$ of ideal body weight. The controls were 10 healthy male volunteers who had undergone minor surgical procedures 8 weeks previously. They were matched for age and body weight. No subject received drugs known to affect glucose tolerance or insulin secretion. A $50 \mathrm{~g}$ oral glucose tolerance test was carried out. Plasma glucose was determined by the glucose oxidase method. Insulin and plasma GIP were measured by radioimmunoassay [5]. The insulin antiserum used binds proinsulin and insulin with equimolar potency. The inter-assay coefficient of variation was $25.7 \%$ at $7 \mu \mathrm{U} / \mathrm{ml}$ and $7.1 \%$ at $52 \mu \mathrm{U} / \mathrm{ml}$. The intra-assay coefficients of variation were $1.4 \%$ and $8.4 \%$ at the same concentrations. Plasma GIP was measured by a single antibody radioimmunoassay. The anti-GIP serum used in the assay reacts primarily with the $5000 \mathrm{~mol}$. wt. component in human plasma [6]. The lower limit of detection was $20 \mathrm{pg} / \mathrm{ml}$ (zero standard $\pm 2 \mathrm{SD}$ ). A reference plasma with a GIP concentration of $640 \mathrm{pg} / \mathrm{ml}$ showed an inter-assay coefficient of variation of $16 \%$ and an intra-assay coefficient of variation of $14 \%$. Non-parametric analysis (Mann-Whitneys rank sum test) was used for analysis of the results. Glucose, insulin, and GIP areas under the curve above the fasting levels plotted over a period of $3 \mathrm{~h}$ were measured by planimeter.
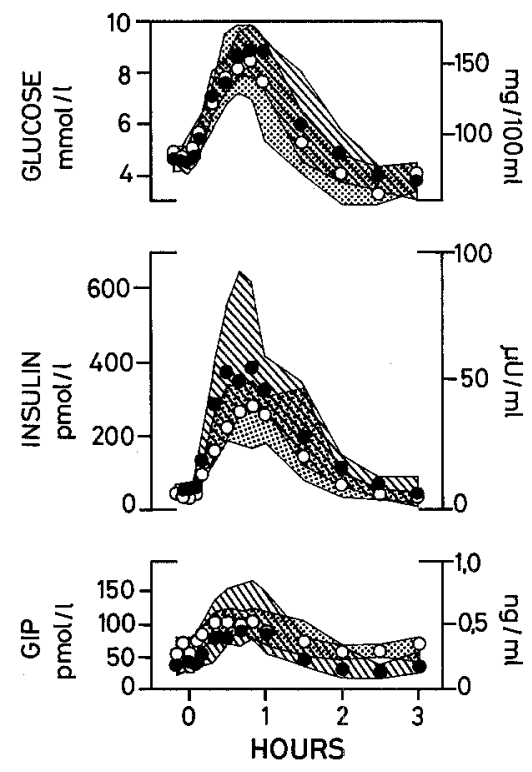

Fig. 1. Plasma glucose, plasma insulin, and plasma gastric inhibitory polypeptide (GIP) during an oral glucose tolerance test in ten patients recovered from acute myocardial infarction $(\bullet)$, and in ten healthy controls $(\mathrm{O})$. The concentrations are shown as median \pm interquartile range (patients: striped area, controls: dotted area) 
Table 1. Plasma glucose, insulin, and gastric inhibitory polypeptide (GIP) responses to an oral glucose load (50 g) in patients recovered from acute myocardial infarction and control subjects

\begin{tabular}{|c|c|c|c|c|c|c|}
\hline & $\begin{array}{l}\text { Basal glucose } \\
(\mathrm{mmol} / \mathrm{l})\end{array}$ & $\begin{array}{l}\text { Glucose area } \\
\text { (planimeter } \\
\text { units) }\end{array}$ & $\begin{array}{l}\text { Basal insulin } \\
(\mu \mathrm{U} / \mathrm{ml})\end{array}$ & $\begin{array}{l}\text { Insulin area } \\
\text { (planimeter } \\
\text { units) }\end{array}$ & $\begin{array}{l}\text { Basal GIP } \\
(\mathrm{ng} / \mathrm{ml})\end{array}$ & $\begin{array}{l}\text { GIP area } \\
\text { (planimeter } \\
\text { units) }\end{array}$ \\
\hline Patients & $\begin{array}{l}4.5 \\
(4.0-5.0)\end{array}$ & $\begin{array}{l}27.9 \\
(20.9-37.7)\end{array}$ & $\begin{array}{l}6.0 \\
(5-10)\end{array}$ & $\begin{array}{l}350 \\
(287-1054)\end{array}$ & $\begin{array}{l}0.20 \\
(0.12-0.20)\end{array}$ & $\begin{array}{l}23.1 \\
(10.8-36.9)\end{array}$ \\
\hline \multirow[t]{2}{*}{ Control subjects } & $\begin{array}{l}4.8 \\
(4.1-5.4)\end{array}$ & $\begin{array}{l}19.2 \\
(11.4-32.0)\end{array}$ & $\begin{array}{l}4.0 \\
(4-5)\end{array}$ & $\begin{array}{l}270 \\
(186-342)\end{array}$ & $\begin{array}{l}0.26 \\
(0.20-0.30)\end{array}$ & $\begin{array}{l}28.2 \\
(16.3-37.7)\end{array}$ \\
\hline & $p>0.10$ & $p>0.10$ & $p<0.05$ & $p<0.05$ & $p>0.10$ & $p>0.10$ \\
\hline
\end{tabular}

Median values and interquartile ranges in parentheses.

\section{Results}

None of the subjects had evidence of glucose intolerance. Median glucose concentrations in the fasting state and during the oral glucose tolerance test were identical in patients and control subjects (Fig. 1). Both the basal plasma insulin concentration and the integrated insulin response to glucose were significantly greater in the post-myocardial infarction patients $(p<0.05)$ (Table 1). Fasting GIP concentrations and integrated GIP response during an oral glucose tolerance test were not significantly different between patients and control subjects.

\section{Discussion}

The patients in this study had made a good recovery from their myocardial infarction and were not receiving treatment with any agents which might affect insulin secretion or glucose tolerance. Our findings of an absence of glucose intolerance are in contrast to what has been reported elsewhere [7]. Hyperinsulinaemia is commonly found in subjects with coronary artery disease with or without abnormal glucose tolerance [8]. This may indicate a state of peripheral insulin resistance in some of these patients in whom a normal glucose tolerance is maintained by increased circulating insulin concentrations. It has been argued that hyperinsulinaemia might promote atherosclerotic processes [8] and thus influence the development of coronary artery disease [9]. However, in one report $20 \%$ of patients with definite myocardial infarction had normal coronary arteries investigated by coronary arteriography [10], and so it remains uncertain whether the increased insulin secretion after myocardial infarction is causally related to the development of atherosclerosis of coronary arteries. Alternatively, other factors involved in the aetiology of myocardial infarction may cause hyperinsulinism. The normal GIP response after oral glucose might be the result of suppression by the concomitant hyperinsulinism excerting a negative feedback control on GIP release. However, it has been shown that insulin does not suppress glucose induced GIP release [11]. Another possibility is that the utilization of nonesterified free fatty acids by the GIP cell may interfere with GIP secretion [12]. In conclusion we have not found any evidence of an elevated GIP response in hyperinsulinaemic patients recovered from myocardial infarction.

\section{References}

1. Peters N, Hales CN (1965) Plasma-insulin concentrations after myocardial infarction. Lancet 1: 1144-1145

2. Tzagournis M, Chiles R, Ryan JM, Skillmann TG (1968) Interrelationship of hyperinsulinism and hypertriglyceridaemia in young patients with coronary heart disease. Circulation 38: 1158-1163

3. Nikkilä EA, Miettinen TA, Vesenne M, Pelkonen R (1965) Plasma-insulin in coronary heart disease. Lancet 2: 508-511

4. Dupré J, Ross SA, Watson D, Brown JC (1975) Stimulation of insulin secretion by gastric inhibitory polypeptide in man. $J$ Clin Endocrinol Metab 37: 826-828

5. Lauritsen KB, Moody AJ (1978) The response of gastric inhibitory polypeptide (GIP) and insulin to glucose in duodenal ulcer patients. Diabetologia 14: 149-155

6. Lauritsen KB, Moody AJ (in press) The association between plasma GIP and insulin after oral glucose. Scand J Gastroenterol

7. Aronow WS, Prakash R (1978) Carbohydrate intolerance and acute myocardial infarction. In: Zoneraich S (ed) Diabetes and the heart. Thomas, Springfield, pp 156-160

8. Stout RW (1979) Diabetes and atherosclerosis - The role of insulin. Diabetologia 16: 141-150

9. Opie LH, Stubbs WA (1976) Carbohydrate metabolism in cardiovascular disease. Clin Endocrinol Metab 5: 703-729

10. Hansen JF (1978) Coronary arteriographic findings in patients with previous acute myocardial infarction. Acta Med Scand 204: 397-399

11. Andersen DK, Elahi D, Brown JC, Tobin JD, Andres R (1978) Oral glucose augmentation of insulin secretion. J Clin Invest 62: 152-161

12. Creutzfeldt W, Talaulicar M, Ebert R, Willms B (1980) Inhibition of gastric inhibitory polypeptide (GIP) release by insulin and glucose in juvenile diabetics. Diabetes 29: 140-145

Received: 8 December 1980

Final form: 23 March 1981

Steen Larsen, M. D.

Hvidøre Hospital

Emiliekildevej 1

DK-2930 Klampenborg, Denmark 